\title{
Examination of Paintings of Naive Artists from Urfa in Terms of Colors, Compositions, Space and Subjects
}

\author{
Urfalı Naif Ressamların Resimlerinin Renk, Kompozisyon, Mekân ve Konu Açısından \\ İncelenmesi
}

\section{Sait Toprak*}

\begin{abstract}
Naive art is the kind of art that is performed independently of the artistic characteristics of a certain period in art history, art movement and theory. Naive artists, who do not have any vocational education history, work with their inner creative impulses without using any academic painting techniques and having contemporary art inclinations. Naive artists come from various socio-economic backgrounds and have various occupations. They mostly handle subjects such as their childhood memories, ordinary scenes of everyday life in the environment where they grew up, and subjects related to folk art. However, there are examples of fantastic, symbolic, surrealistic, satirical and critical content, as well as historical and social aspects, which also come into prominence in the works of Naive artists, who do not self-censor what they think and feel. The works of Naive artists differ from the works of amateurs and countryside artists who have received art education in terms of their content and execution of shapes. In the same way, folk art that depicts traditional culture cannot be evaluated in the same art category as Naive art. Each element in these paintings, which are created with childish sensitivity, is described in finest details and with attentive insight. Most of the time, Naive artists work without worrying about the rules of art like perspective, dimensions or balance and without making comparison between their own work and other pieces of art in an academic sense during the creation process, since they focus on the story or events to be depicted in their work. The Naive artist tries to introduce new worlds, new phenomena, by discovering new details during the process of production. In this study, some evaluations concerning the historical evolution of Naive art and its reflections on Turkey will be made. Secondly, the works of Namuslu Ali, Osman Görgün, Şefika Güneş, Naci Büyükkırcalı, Abdurrahman Birden, Abdurrahman Polat, Neşet Uçkan, Necmi Kaya and Muharrem Çelik, some of the Naive artists from Urfa who work with a Naive approach bringing local motifs and themes into the forefront, are examined in terms of characteristics of colors, composition, space and subjects.
\end{abstract}

\section{Keywords}

Naive Art, Naive Painters, Urfa, Naive Artists from Urfa

\section{Öz}

Naif resim, sanat tarihinde belli bir dönemin, akımın ve kuramın sanatsal özelliklerinden bağımsız bir şekilde çalışmaların yapıldığı bir türdür. Mesleki bir eğitim geçmişi olmayan naif ressamlar, akademik resim tekniklerine sahip olmadan ve güncel sanatsal eğilimlerden uzak şekilde iç yaratıcı dürtülerine göre çalışırlar. Naif ressamlar, farklı sosyo-ekonomik yapıya ve mesleklere sahip çevrelerden gelirler. Çalışmalarında çoğunlukla çocukluk anılarını, doğup büyüdükleri çevrenin sıradan yaşam sahnelerini ve halk sanatıyla ilişkili konuları ele alırlar. Düşündüklerini ve hissettiklerini sansüre tabi tutmadan aktaran naif ressamların çalışmalarında fantastik, sembolik, gerçeküstücü, yergilerin ve eleştirel içeriklerin yanı sıra tarihsel ve sosyal

* Correspondence to: Sait Toprak (Asst. Prof. Dr.) Kafkas University, Faculty of Fine Arts, Department of Painting, Kars, Turkey. E-mail: sait_toprakart@hotmail.com, ORCID: 0000-0001-7820-4685

To cite this article: Toprak, Sait. "Examination of Paintings of Naive Artists from Urfa in Terms of Colors, Compositions, Space and Subjects." Art-Sanat, 14(2020): 441-467. https://doi.org/10.26650/artsanat.2020.14.0017 
sorunları irdeleyen yönlerin de ön plana çıktığı görülebilmektedir. Naif ressamların çalışmaları, içerik ve biçim uygulamaları açısından, sanat eğitimi görmüş amatör ve taşralı ressamların üretimlerinden farklıdır. Aynı şekilde geleneksel kültürü oluşturan halk sanatı da naif sanat kategorisinde değerlendirilmez. Çocuksu bir duyarlılıkla yaratılan resimlerde her öge, titiz bir anlayışla en ince ayrıntısına kadar betimlenir. Naif ressamlar, anlatılan hikâye ve olaya odaklandığından çoğu zaman perspektif, ölçü ve denge gibi sanatsal kurallara uyma konusunda kaygı duymadan ve yaratım sürecinde akademik anlamdaki sanat ürünleriyle karşılaştırma yapmadan çalışırlar. Naif ressam, ortaya çıkardığı resimlerin yapım aşamasında yeni detaylar keşfederek yeni olguları, dünyaları anlatmaya çalışır. Bu çalışmada, öncelikli olarak naif resmin tarihsel gelişim sürecine ilişkin bazı değerlendirmeler yapılmış ve Türkiye'deki yansımaları ile birlikte yerel motif ve temaları ön plana çıkaran Urfalı naif ressamlardan Namuslu Ali, Osman Görgün, Şefika Güneş, Naci Büyükkırcalı, Abdurrahman Birden, Abdurrahman Polat, Neşet Uçkan, Necmi Kaya ve Muharrem Çelik'in çalışmaları renk, kompozisyon, mekân ve konu özellikleri bakımından incelenmiştir.

Anahtar Kelimeler

Naif Resim, Ressam, Urfa, Urfalı Naif Ressamlar

\section{Genisletilmis $\ddot{O}_{z, e t}$}

Naif resim, sanat tarihinde belli bir dönemin, akımın ve kuramın sanatsal özelliklerinden bağımsız bir şekilde çalışmaların yapıldı ğı bir resim anlayışıdır. Mesleki bir eğitim geçmişi olmayan naif ressamlar, akademik resim tekniklerine sahip olmadan ve güncel sanatsal eğilimlerden uzak şekilde iç yaratıcı dürtülerine göre çalışırlar. Çalışmalarında çoğunlukla doğup büyüdükleri çevrenin sıradan yaşam sahnelerini ve halk sanatıyla ilişkili konuları ele alırlar. İmgelem dünyalarını doğrudan aktaran naif ressamların çalışmalarında fantastik, sembolik, gerçeküstücü, yergilerin ve eleştirel içeriklerin yanı sıra tarihsel ve sosyal sorunları ele aldıkları görülebilmektedir. Çocuksu bir duyarlılıkla yaratılan resimlerde her biçim, titiz bir anlayışla en ince ayrıntısına kadar resmedilir. Naif ressamlar, anlatılan hikâye ve olaya odaklandığından çoğu zaman perspektif, ölçü ve denge gibi sanatsal kurallara uyma konusunda kaygı duymadan ve yaratım sürecinde akademik anlamdaki sanat ürünleriyle karşılaştırma yapmadan çalışırlar.

Urfa'daki mahallî ressamlık geleneğinde konuların kurgulanış biçimi ve izleyiciyle kurdukları bağ açısından "Urfalı foto-yorumcu/gerçekçi”" tarzda çalışan ressamlardan ayrı olarak ortak bir eğilim gösteren naif ressamların çalışmalarında önemli bir yaratıcılığın olduğu ve naif resmin genel özellikleri açık bir şekilde görülebilir. Urfalı naif ressamlar üretim sürecinde çevreden herhangi bir müdahale ve yardım almadan bireysel olarak, kendi düşsel dünyalarına ve izlenimlerine dayanarak resim yapmaktadırlar. Bu resimlerin teknik yönünden ve evrensel boyutundan söz edilebilir. Ancak bu resimler, konu bakımından yerel aklın ve beğeninin ürünleri olarak ortaya çıkmıştır. Çalışmalarda yoğun bir gerçekçiliğin yanı sıra düşsel unsurların, sözlü halk edebiyatının ve folklorik değerlerin yansımalarını görmek mümkündür. Ressamların olabildiğine saf ve yalın bir anlayışla yaptıkları resimlerin, yaşanmışlığın imgelemdeki izdüşümleri olarak üretildikleri söylenebilir. Bu yönüyle, Urfalı naif ressamların çalışmalarının, sanat piyasasının tüketim ve asimile eden ortamından uzak ve çağdaş/ akademik/entelektüel sanatsal kalıplara başvurulmadan yapılmış Türkiye'deki gerçek 
naif sanatın önemli örnekleri olduğu ileri sürülebilir. Bu çalışmada, üslup anlayışı ve bakış açısıyla yerel yaşamı ve folklorik temaları resimlerinde önemli bir öge ve imge olarak ele alıp yorumlayan farklı kuşak ve anlayışta resim yapmış ressamlara değinilmiştir. Akademik resim anlayışından ve dış etkenlerden tamamen bağımsız, naif sanat anlayışı doğrultusunda ve bireysel yaklaşımlarla çalışmalar üretmiş olan Urfalı naif ressamlardan Namuslu Ali, Osman Güngör, Şefika Güneş, Naci Büyükkırcalı, Abdurrahman Birden, Abdurrahman Polat, Neşet Uçkan, Necmi Kaya ve Muharrem Çelik'in çalışmaları naif resim ekseninde incelenmeye çalışılmıştır.

Çalışmaları ve renkli yaşantısından dolayı Urfalı naif ressamlar içinde en ilginç ressam, (asıl işi oto boyacılı̆̆ı olan) Namuslu Ali lakabıyla bilinen Ali Tökgöz'dür. Bir dönem Urfa'nın birçok iş yerinin tabelasında ve duvarında resimleri bulunan Namuslu Ali'nin ne yazık ki günümüze sadece ahşap plaka üzerine endüstriyel yağlı boya ile yaptığı iki resmi ve Müslüm Parmaksız Evi'nin duvarına yaptı̆̆ı bir resmi ulaşmıştır. Namuslu Ali, Urfa'nın tarihi yerlerini konu aldığı resimlerini naif bir resimleme anlayışıyla ve olasılıkla hayalden resmederek yapmıştır. Urfalı naif ressamlar içinde değerlendirilen diğer önemli ressam Osman Görgün'dür. Çalışmalarında yoğun olarak horozları ve horoz dövüşlerini konu edinen Görgün'ün, resimlerinin bazı açılardan akademik bir bilinçle yapıldığı hissedilir. Ancak resimler yakından incelendiğinde, resmin imgelenişinde ve biçimleniş̧inde naif anlayışın egemen olduğu ve zorlama bir boyamanın olmadığı, rahat ve içtenlikle yapıldığı açıkça gözlemlenmektedir. Grubun öne çıkan bir diğer ressamı ise Nine Ressam olarak bilinen Şefika Güneş’tir. Okuma yazması olmayan ve ileri bir yaşında resim yapmaya başlayan Güneş'in çalışmalarında doğduğu, büyüdüğü köy yaşantısının yanı sıra yerel halk edebiyatından geniş ölçüde yararlandığının izlerini görmek mümkündür. Güneş, çevresindeki akademik ve foto-yorumcu ve amatör ressamların resim anlayışına hiç özenmeden, naif karakterini yitirmeden çocukluk anılarına ilişkin pek çok ögeyi, manzarayı koruyabilmiş ve bunları sade bir gerçeklikle resimlerine yansıtabilmiştir. Resimlerindeki abartı, basitlik, yalınlık ve olağanüstülük gibi durumlar gerçeklikten kaçış veya onu yapamamasından değil, daha çok düşsel yanı ve coşkuyu ön plana çıkarmasındandır. İşçi emeklisi olan Naci Büyükkırcalı, resimlerinde Urfa'da günümüzde kaybolmuş el sanatlarının, yıkılmış/yıktırılmış ve tahrip olmuş yapıların, eski Urfa evlerindeki ev ahalisinin günlük yaşam sahnelerini sabırlı ve titiz bir boyama tekniğiyle, kendine özgü üsluplaşmış naif bir dille betimlemektedir. Büyükkırcalı'nın resimlerinin naif ve naif olmamak arasında bir yerde olduğu söylenebilir. Çünkü bazı resimlerinde fırçasını ustalıkla kullanmasının yanı sıra sağlam kompozisyonların, büyük bir dikkatle ve özenle biçimlendirilmiş ve renklendirilmiş bir teknik ile yapıldığı görülür. Ressamlığa şövale tabelacıllğı ile başlamış olan Abdurrahman Birden'in resimlerinin önemli bir bölümünde, Urfa'daki günlük yaşam sahnelerine ilişkin tasvirlerin varlığı göze çarpar. Bir zamanlar her bayramda Urfa'nın çeşitli mahallelerinde kurulan tahtadan salıncak ve dönme dolaplar, sokak aralarına kurulan şehriye makineleri, halı örenler, Abdurrah- 
man Birden'in belleğinde yer etmiş ve buna benzer birçok çalışmayı kendine özgü üslubuyla, katışıksız olarak resmetmiştir. Abdurrahman Birden'in naif boyamanın yanı sıra tabelacı titizliğiyle ve ince firça vuruşlarıyla resimlerini sabırlı bir şekilde yaptığı görülür. Şövale tabelacıllğından gelen bir diğer naif ressam ise Abdurrahman Polat'tır. Yıllarca kamyon, römork, okul, resmî kuruluş/daire, kıraathane, hacı duvarı ve dinî mekânları çalışmalarıyla süsleyen Polat; zaman buldukça çocuksu bir coşkunun yanında âdeta bir resim işçiliği ile yaptığı, kırsal yaşamı kendine özgü vurgularla betimlediği resimleriyle Urfa'daki naif resmin konu ve biçim yönünden çeşitlenmesine ve gelişmesine önemli katkı sağlamıştır. Düş gücüyle oluşturulan bu çalışmalarda herhangi bir müdahale veya yönlendirme gözlemlenmemektedir. Aksine, saf ve titiz bir duyarlılıkla yapılmış resimlerdir. Asıl mesleği eczacılık olan ve daha sonra resim yapmaya başlayan Neşet Uçkan'ın sakin ve rahat tarzında güzelleştirmeci ve zorlayıc1 bir resimlemenin olmadığı görülmektedir. 1985 yılından bu yana tutarlı bir şekilde pastel boya kullanarak yaptığı Harran resimleriyle Urfalı naif ressamlar arasında konu ve teknik yönünden ayrı bir yerde duran Necmi Kaya, zamanla kendine özgü bir naif resim dili geliştirmiştir. Kaya'nın resimlerinde daha çok Harran'daki geleneksel yaşantının çeşitlemeleri görülmektedir. Bu çeşitlemelerde; onun saf bir içtenlikle Harran manzarasına ilişkin bir dizi tutarlı görsel düşünceler ürettiği izlenebilir. Akademik bir sanat eğitimi almamış olan Muharrem Çelik'in, sıra dışı içerikteki anlatımı ve tarzıyla Urfalı naif ressamlar grubunda kendine özgü bir yeri vardır. İmgelerin betimlenişi açısından naif-dışa vurumcu olarak değerlendirebileceğimiz resimlerde, yoğun olarak çiğ ve pastel renkler kullanılmıştır. Naif bir duyarlılığın yanı sıra mizahın ve yerginin olduğu çalışmalarda ilginçlik ve içtenlik birçok açıdan duyumsanmaktadır.

Sonuç olarak, Türkiye naif resminde saklı kalmış estetik bir değer olarak değerlendirilebilecek Urfalı naif ressamlar, yaşadıkları çevrenin yaşantısını kişisel, estetik, kurgusal, saf ve titiz bir resim anlayışıyla betimlemişlerdir. Urfalı mahallı̂ ressamlık geleneğinde naif tarzda çalışan ressamlar; naif resmin genel özellikleri çerçevesinde, yerel aklı ve beğeniyi birbirine eklemleyerek, hiçbir sanatsal biçime entegre olmadan, üretim sürecinde çevreden herhangi bir müdahale ve yardım almadan, kendilerine özgü ortak bir konu etrafında bireysel, güçlü, naif bir resim dili oluşturmayı başarmışlardır.

Teknik açıdan Urfalı naif ressamların resimlerine bakıldığında, her ressamın kendi içgüdülerine ve sezgilerine bağlı olarak, yaşamsal deneyiminden ve gerçekliğinden yola çıkarak resimler ürettiği izlenebilmektedir. İncelenen bazı örneklerde, gerçekçi ve detaycı bir resimleme üslubunun ve yumuşak renk geçişlerinin olduğu, bazı örneklerde ise daha yüzeysel ve yalın bir biçimleme anlayışının hâkim olduğu görülebilmektedir. Bireysel sanatsal deneyim ve birikime göre kimi ressamların resimlerini sağlam bir kompozisyon, figür ve perspektif kullanarak yapılandırdığı izlenebilirken kimi örneklerde ise çocuksu bir duyarlılıkla saf, katışıksız bir resimlemenin ön plana çıktığı görülebilmektedir. 


\section{Introduction}

In order to mark the boundaries and contents of Naive art as an important genre in the art of painting, the meaning of the word "Naive" must first be defined . Besides its use to refer to that which is pure, natural, innocent, plain and that which is not pretentious, the word "Naive", which is derived from the Latin word nativus, ${ }^{1}$ is used also to refer to "artists, who see the truth and nature with a new eye, who redraw them and who develop an inexperienced and crude style." ${ }^{2}$ It is hard to tell when exactly Naive art emerged. However, the drawings on the walls of the Altamira and Lascaux caves, which were drawn by humankind to reflect their life experiences for various reasons and purposes, can be considered to be the first examples of Naive art. Gombrich ${ }^{3}$, who states that these paintings are the oldest impressions of human skills, says that the compositions were mostly drawn in a disorganized way where each one was painted or carved up on another independently. It can be observed that these first drawings, which carry traces of perception, mentality and lifestyles of humans, have similarities with the works of contemporary Naive artists.
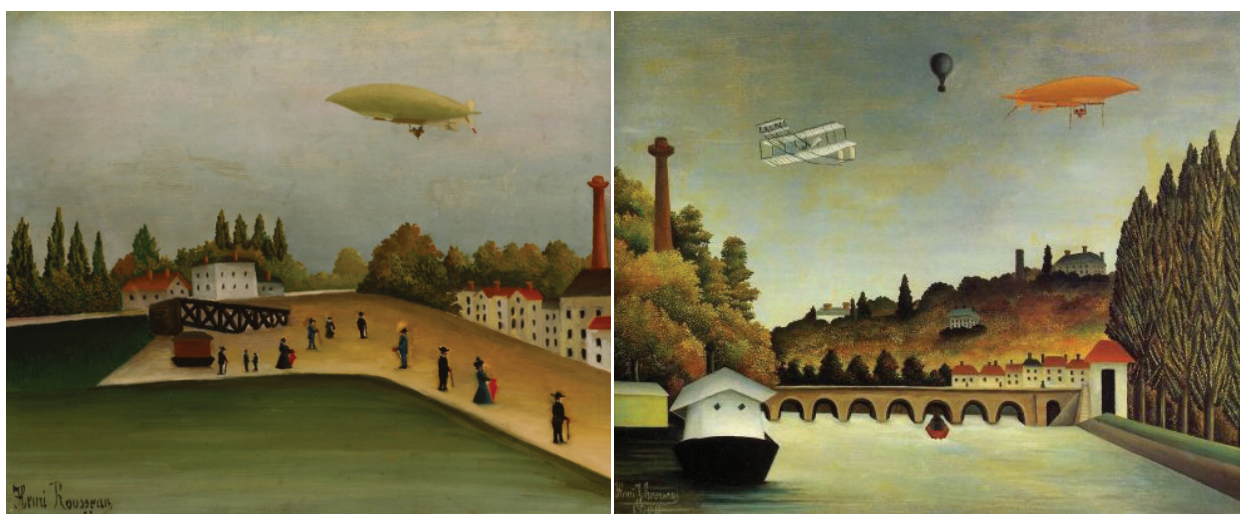

F. 1. Henri Rousseau, Landscape with Zeppelin, 1907, Oil on Canvas, 46.1 x $55 \mathrm{~cm}$. (Bridgestone Museum of Art, Tokyo, https://arthive.com/henrirousseau/works/324683 Landscape_with_a_ dirigible.).

F. 2. Henri Rousseau, View of the Bridge of Sevres, 1908, Oil on Canvas, 81 x $100 \mathrm{~cm}$. (Pushkin Museum of Fine Arts, Moscow, http://www.canvasreplicas.com/Rousseau105.htm.).

The usage of the word "Naive" as an art term or concept differs depending on the historical period within which it is used. In the $17^{\text {th }}, 18^{\text {th }}$ and $19^{\text {th }}$ centuries the word was used to refer to a mode of articulation in literature or detail in poetry and it sometimes had a positive and at other times a negative meaning. Poets and historians such as John

1 Library of Universal Knowledge-The Practical Self-Educator, ed. Franklin J. Meine (Chicago: Consolidated Book Publishers, 1963), 478.

2 Kaya Özsezgin, Sanat Üzerine Yazılar (İstanbul: Cumalı Sanat Galerisi Yayınları, 1982), 143.

3 Ernst H. Gombrich, Sanatın Öyküsü, trans. Erol Duman and Ömer Erduman (İstanbul: Remzi Kitabevi, 1999), 41-42. 
Dryden, Alexander Pope, David Hume and Carly are among the people who made extensive use of the word "Naive" as a term. Friedrich Schiller takes "Naive" and "sentimental" as concepts of art in his book "Naive and Sentimental Poetry". According to Schiller, Naive poetry is a natural style of poetry produced while looking at the object. Nature, art and ideal are three stages and these correspond with Naive, sentimental, and synthetic stages in poetry. On the other hand, the use of the word "Naive" as a term in plastic arts coincides with the period when abstract art spread around the world at the end of the $19^{\text {th }}$ and beginning of the $20^{\text {th }}$ century. Naive art emerged in Montmartre with both Fauvism and Cubism before the First World War and it was supported by poets like Guillaume Apollinaire. Naive art became accepted in the post war era. ${ }^{4}$

Naive art began to take its place in the tradition of western art as genre of art right after the German art critic and collector, Wilhelm Uhde, introduced and adopted the works of a group of artists who produced their paintings in their leisure time at the end of the $19^{\text {th }}$ century. The most renowned artist among them is Henri Rousseau (18441910). Some of the art historians and critics regard Rousseau as one of the pioneers of modern art because of the sincerity in his paintings, his stance against academism and his detachment from all set standards. It is known that not only art collectors and dealers but also literary figures put great emphasis on the importance of Naive art. Rimbaud, the poet, stated that the paintings that were painted in a Naive and unskilled style should be loved and considered as important. Nobody had ever thought that this mysterious world created outside the circulation of art, uninformed by art movements and styles of the time would make a great contribution to contemporary art. However, artists began to emerge who attributed importance to this style and who suggested that Naive painting was a kind of art in its own right ${ }^{5}$. In accordance with such developments, Naive art began to be regarded separately from folk art. Henri Rousseau, whose works have all of the characteristics of Naive art, has been accepted as the pioneer of all painters working in this perspective. "The paintings of Rousseau have a childish expression and a Naive and independent language (F. 1, F. 2). Yet, beyond this point of view, a maturity different than a child's painting strikes the eye. ${ }^{16}{ }^{6}$ Herbert Read $^{7}$ regards Rousseau as the most intriguing artist in art history after Cezanne, Van Gogh and Gaugin. Writers such as Remy de Gourmont, Jarry and Andre Salmon all together embarked upon promoting Rousseau, who was labeled as grotesque; ignored and laughed at. Wilhelm Uhde used the term "Naive painters" for the first time, to refer to the painters who gathered around Rousseau and who were considered as interesting due to their styles and ways of living. ${ }^{8}$

\footnotetext{
4 Fahir Aksoy, Naif Sanat ve Türk Naifleri (İstanbul: Ak Yayınları, 1990), 5-27.

5 Özsezgin, Sanat Üzerine Yazılar, 146.

6 Sevim Erdem, Modern Sanat (İstanbul: Türkiye Basımevi, 1963), 199.

7 Herbert Read, Sanatın Anlamı, trans. Güner İnal and Nuşin Asgari (İstanbul: Türkiye İş Bankası Kültür Yayınları, 1974), 149.

8 Özsezgin, Sanat Üzerine Yazılar, 146.
} 
The lack of theoretical and abstract framework is a distinctive characteristic of the works of Naive painters who did not receive any academic or artistic education but who were self-trained and who take their sources mostly from nature, the environment and folklore . Naive paintings, which are produced based upon instincts and intuitions, carry artists' personal characteristics in terms of technique and style. It is observed that there is a large amount of detailed portraiture in Naive paintings in which the painters reflect both their imaginations and impressions from the real world. "They have an artistic value with regard to their portraiture that is created with the perception of "a fairly innocent eye" instead of a reflection technique with an academic external reality.", Most of the time, the audience senses that Naive painters try to express a very detailed surrealism in their paintings, which they create with high power of imagination and with fantastic (sometimes satirical) elements. In the process of producing paintings, artists use content, style, and various textures and techniques freely. Contrary to some general perceptions about Naive art, some pieces of this form of art can be observed in which perspective and stylistic balance have been used at an excellent level, where strong compositions are created, and where strong figure portraitures, rhythm and balance are used correctly. ${ }^{10}$ A large number of Naive painters make no preliminary preparations, designs or drafts before beginning a painting; ${ }^{11}$ they mostly paint with an improvisation. It is known that a lot of Naive painters finish the paintings, which they begin by improvising, without any problems, and because they do not have the notion of changing, erasing, or redoing the paintings, they only make some very minor changes and interventions.

Since they have no connection with the professional painting world, Naive painters use dyes that they obtain locally or even special materials they make themselves. ${ }^{12}$ It is known that most of the Naive painters painted their first paintings on wooden surfaces, wax cloth or paper and only later used canvas. Becker states that "Naive painters produce their works on their own without minding the cooperative limitations of art world that restrains contributors and they produce works of art, which do not fit in any particular set standards and which cannot be described as an example of a particular class on their own." ${ }^{13}$ Naive painters do not know other artists who produce works of art that are similar to their own. They have very limited knowledge about the field of art they are interested in, its genre and history, and about artistic norms, conventional methods and practices or the quality of the works of art produced in this field of art. Since they only know the painters and their styles in their own environment, they can only compare themselves with them. Naive artists cannot learn the traditional art

9 Metin Sözen and Uğur Tanyeli, Sanat Kavram ve Terimleri Sözlüğü (İstanbul: Remzi Kitabevi, 2007), 170.

10 Aksoy, Naif Sanat ve Türk Naifleri, 9.

11 Howard S. Becker, Sanat Dünyaları, trans. Evren Yılmaz (İstanbul: Ayrıntı, 2013), 314.

12 Becker, Sanat Dünyalart, 316.

13 Becker, Sanat Dünyalar, 310-311. 
repertoire, which might explain both the reason why they produce their works and the characteristics thereof since they have no professional education and no connection with the traditional art world. As they cannot explain what they do by using art terminology, and as what they do cannot be defined as anything but art, Naive artists have problems with people who demand an explanation from them. ${ }^{14}$

Ana Jakovsky writes her thoughts about Naive art in a journal, Insitiá, which is published in Czechoslovakia and devoted only to Naive art, after giving some information on Naive art as follows:

\footnotetext{
"A great many men and women may find themselves in plastic resonance in a certain sense regardless of their age, social strata and cultural development levels. They can make contributions that cannot be counted as insignificant. This creative activity is determined and identified in accordance with all of the ways expressing the thoughts of people. Yet, Naive art cannot be attained from here. The sentimental effect in the masterful Naive art depends on the surprise of the never-seen-before. This is a kind of art that destroys our acquired habits in looking at objects, shakes our knowledges, and forces out intellectual comfort." ${ }^{\prime 15}$
}

In the $3^{\text {rd }}$ issue of the journal, Insitiá, in his article "Naive Painters", Miroslav Míčko (1912-1970) states that art has broken its ties with natural inspiration sources and life as it began to compete with the developing science and technique in the fast progressing age we live in. Míčko then continues: "We come across the family of Naive painters that makes us return to our human essence in an enchanting way, and affects us with the childish purity and style of perception. In a way, they represent the endlessly creative existence of people in the determined relations of the contemporary world." ${ }^{16}$ On the other hand, Arsén Pohribný states that Naive painters share various perceptions, thinking and impressions of the public and yet they do not affiliate, on a common level, with the public with regards to senses, thinking and artistic abilities. He defines the portrait of the Naive artists by marking the distinction between artists who are trained in an academic perspective as follows:

"It is important for the Naive artist to tear himself off the environment. It is especially
important to tear oneself off from the contemporary elite cultural development and the
rational education patterns both of which debase the instinctive and childish imagi-
nation. For some reason, in our minds the concept of the artist is strictly attached to
education and technique. However, the reason for a self-educated artist to be successful
on such a scale in the contemporary art world is that he can protect his originality from
the influence of artistic conventions. Another difference between a professional artist

14 Becker, Sanat Dünyalarl, 309-317.

15 Aksoy, Naif Sanat ve Türk Naifleri, 11.

16 Aksoy, Naif Sanat ve Türk Naifleri, 12. 
and a Naive artist is the chosen purpose of art. Most of the professionals do not easily give up marketable items and things that might build a professional reputation for them. This kind of marketing oneself is alien to the Naive artist. The Naive artist, never pays a compliment to the contemporary fashion and the technical and essential taboos, which can affect professional artists, do not affect them. With this, we do not mean that the Naive denies the technique. However, instead of being stuck with techniques that are strange to itself it rather gives life to specific techniques that will suit to exteriorize its own original values. ${ }^{17}$

Even if the term "Naive art", was used to refer to the purest of arts and to the painting language that is obtained from distilling images from its own self without adhering to any art movement and technique, later on it was understood that the term fell short in its definition of this artistic style and a need for neologism emerged. For example, Jean Dubuffet's term, Art Brut, which means Unprocessed Art, describes art which is "not yet adulterated by culture." Some artists live in mental hospitals or in an environment which is purified from educational, cultural, and traditional impacts. According to Debuffet, Art Brut is the purest form of visual creation, the flowing of a spiritual inner reaction from the mind to the paper. Though not as widespread as Art Brut, other terms have also been used. Books were written on them and even museums were opened. Neuve Invention, though it fits into the same category as Art Brut since the boundaries of this term were limited by Dubuffet, has been reserved for the works of art of artists who have more relations with the world. ${ }^{18}$

As dispute over which name or term should be used to define Naive art continues, it can be observed that this art is practised and conceptual discussions on it take place in detail in Eastern European countries. The discussions regarding the definition of Naive art and its style are mostly about defining the boundaries of naive art from other kinds of art, and about staying away from and eradicating the usual and somehow standardized conventions of Naive art. An institution in the city of Bratislava (now the capital of Slovakia) in Czechoslovakia, which organizes triennial exhibitions around the journal, Insitiá, the term Insite, put forth by Czech thinkers, especially Stefan Track, and a declaration that underlines the necessity to introduce a new definition for this art created a great impact and one meeting followed another. The aim was to provide a place for this genre of art that fits itself within the frame of contemporary artistic expression. ${ }^{19}$ Yugoslavia is another country in which Naive art has shown considerable development. Stating that Naive art has become a school in its own right in Yugoslavia and that a lot of folk artists have grown up there, Özsezgin ${ }^{20}$ clarifies

17 Aksoy, Naif Sanat ve Türk Naifleri, 11-12.

18 Ayda Şirin Manukyan, Naif Resmi, Cumhuriyetin Renkleri ve Biçimleri, ed. Ayla Ödekan (İstanbul: Tarih Vakfi Yayınları, 1999), 40.

19 Aksoy, Naif Sanat ve Türk Naifleri, 33.

20 Özsezgin, Sanat Üzerine Yazılar, 151. 
the aforementioned developments as follows: Since Naive painters are born and have grown up in the village of Hlebine, or since they gather there, Yugoslavian Naive painters merge under the name of the Hlebine School. The pioneers of this school, who are also recognized in the international art world, are Ivan Generalić (1914-1992), Ivan Rabuzin (1921-2008) and Mirko Virius (1889-1943). The common features of these painters are that they typically paint various scenes from daily village life as it is and that their portrayals are impulsive. Despite all these historical efforts regarding Naive art, it can be observed that some visible corruption has emerged in time. Özsezgin states that:

"Those who have chosen to abuse the real and sincere sensitivities of Naive painters,
in other words, those who tried to bring forward Naiveté as a factitious art language,
thought that a shallow approach to the problem was enough just like the fake abstrac-
tionists. (...) If it is easy to distinguish fake abstractionist from the real ones, the same
is also true in distinguishing fake Naive artists and it is quite possible to give the latter
the place they deserve."

It can be said that Naive art has some influence on the original production of contemporary artists. For example, academic artists, or in other words, intellectual artists, typically produce works of art by applying images and styles of Naive art. Some see it in the works of some important painters like Le Nain, Chardin, Corot, or even Ingres. As for artists such as Chagal, they combine agglomerative and folkloric inspirations with some aspects of Naive art. Naive elements in the works of Edgar Tytgat, Jean Fautrier, Otto Dix and George Grosz, Ben Shahn and Picasso cannot be overlooked. ${ }^{22}$

\section{Naive Tendencies in Turkish Painting}

"In spite of the fact that there is an extensive practice of painting that consists of nature and city portraiture in anonymous wall decorations in the $18^{\text {th }}$ and $19^{\text {th }}$ centuries together with westernization, the earliest important Naive painters, Mehmed Siyah Kalem, Matrakçı Nasuh and Nakkaş Osman, were actually painters who were working within miniature tradition. Elaborate craftsmanship as well as a sincere conduct of life and an intense world of imagination strike the eye in the works of these artists." ${ }^{23}$

At the end of the $18^{\text {th }}$ century, the pioneers of Turkish painting under the influence of the West were mostly military men and became known as the primitives of modern art. Since most of these painters, some of whose names are unknown, were the members of a generation which did not have any relation to European art studios and since they did not get a proper academic education in painting, their works can be evaluated

21 Özsezgin, Sanat Üzerine Yazılar, 153.

22 Özsezgin, Sanat Üzerine Yazılar, 154.

23 Jale Erzen, Eczacıbaşı Sanat Ansiklopedisi, vol. 2 (İstanbul: Yem Yayın, 2008), 1126. 
as the product of a personal and sincere sensitivity. ${ }^{24}$ The attention paid to details in the paintings of primitive painters caused them to be identified as primitive. The main theme in the works of these painters are various panoramic images of Yildiz Palace, and gardens, kiosks, mosques, and such places are portrayed in bright colors in a calm environment with no figures. Along with some anonymous pieces of art, paintings of Fahri Kaptan, Osman Nuri Paşa, Salih Molla Aşkî, Ahmed Şekûr, Hüseyin Giritli attract attention. ${ }^{25}$ There are some artists who received an academic education in the West, like Şeker Ahmet Paşa, and who, to some extent, managed to preserve their purity and primitive sensitivity Nonetheless, this period of purity was very short. Not many tendencies or activities with Naive style are encountered until Turgut Zaim and Bedri Rahmi Eyüpoğlu in the 1950s. ${ }^{26}$ It was after the 1950s that artists producing work that carried all the qualities of Naive art began to appear again in the world of art. ${ }^{27}$ In this period, it can be observed that along with all the other changes in Turkey some principal changes took place in the world of art as well. The main reasons for the changes in art life are:

\begin{abstract}
"the fact that artistic behaviors and style values obtained personal characteristics in parallel with the efforts on liberalization of the socio-economic structure, that the inner worlds of artists and the realities regarding their personal lives in the choice of painting themes were foregrounded, that rights of subjective interpretations regarding the transfer of the natural and public environment outside into the language of painting started to be exercised freely and the fact that the problem of local-national values in contrast to universal values in painting occupies the agenda with increasing intensity." 28
\end{abstract}

Bedri Rahmi Eyüboğlu's use of public/folkloric elements in his paintings opened a way to the development of an iconography that could be the source of the Naive style, and Turgut Zaim's paintings, which are full of love and naiveté reflecting village life, prepared an ideological base that could support the genre of Naive painting. There is a Naive tendency in Turkish painting that has been felt in the art market especially since the 1960s. In addition to artists such as İhsan Cemal Karaburçak, Galip Onmat, Cihat Burak, Fahir Aksoy, Oya Katoğlu, Berna Türemen, Yalçın Gökçebağ, Nadide Akdeniz, who illustrate public life and folkloric elements with rich colors and detailed forms, some of the artists that constitute the Naive School are the students of Bedri Rahmi Eyüpoğlu."29

24 Özsezgin, Sanat Üzerine Yazılar, 158.

25 Erzen, Eczacıbaşı Sanat Ansiklopedisi, 1126.

26 Özsezgin, Sanat Üzerine Yazılar, 159.

27 Indigenization and regionalization tendencies that began with choosing subjects about Anatolia to some extent in the 1930s gained acceleration and developed in the 1940s. It is understood that most of the representatives of Naive painting that began to emerge in the 1960s are the artists, who defend the reason for nationalization. See Simge Saraç, “Türkiye'de Naive Resim” (M. A. Thesis, Istanbul University, 1998), 44-104.

28 Sezer Tansuğ, Türk Resminde Yeni Dönem (İstanbul: Remzi Kitabevi, 1990), 11-12.

29 Erzen, Eczacıbaşı Sanat Ansiklopedisi, 1126. 
If Naive art is evaluated only on the basis of some striking, esteemed and prominent examples in Turkish art history, then the domain and boundaries of Naive art in Turkey will be underemphasized. It is thought that since traditional handicrafts, rural painting, and other folk arts, which occupy an extensive domain, have not been recorded there is a high number of unknown Naive painters. Hüseyin Yüce (1928-2015), who quietly lived in his village away from and unaware of all artistic developments and who painted in accordance with his own knowledge, attracted the attention of the painter Cemal Bingöl, and his paintings were displayed in an exhibition at Ankara Gallery of Fine Arts in 1968. All the characteristics of Naive painting can be observed in the paintings of Hüseyin Yüce, who is actually a mason by profession. In the paintings of Yüce, who attended International Triennial of Naive Artists in Bratislava in 1973, "nature generally consists of trees with mystical evocations and houses. Everything from the sky to the earth is painted as if they were buried in a weird silence. (...) He tries to transfer nature as a whole to his paintings without excluding any minute detail." 30

Cihat Burak (1915-1994), who is known for his Naive identity and genius, is an architect by profession. He displays a painter's identity with all the characteristics of Naive art in his paintings and includes minute details in his portraitures. Yet, Burak's characteristic that separates him from his fellow contemporary Naive artists is as follows: The unskillful style that is combined with satire and humor in his paintings connects him with folk humor while it is open to all of the Naive possibilities. ${ }^{31}$ Even though some Naive artists who are categorized under the names of folk art and Naive art later emerged onto the Turkish art scene, even after they produced some pieces of art that are standard to the norms of that scene, it is observed that a genuine Naive understanding is assimilated in the paintings of these artists and that they produced works mainly for the market.

The purpose of this article is first to state that each locality has a unique and consistent appreciation of art in Turkey and, second, to bring to light information that has not yet had a place in Turkish art history as well as introducing artists and their works from Urfa, who perform art from a Naive perspective.

\section{Method}

This study follows the method of qualitative research and in this context two data collection tools are used. The first data collection tool is document analysis and the second is the interviewer's form given to the participants. Procedurally, the purpose of document analysis is to examine systematically both written and visual sources and sort them thematically. ${ }^{32}$ In this way, a certain point of view or hypothesis may

30 Özsezgin, Sanat Üzerine Yazılar, 160.

31 Özsezgin, Sanat Üzerine Yazllar, 161.

32 Bruce L. Berg and Howard Lune, Sosyal Bilimlerde Nitel Araştırma Yöntemleri, trans. ed. Hasan Aydın 
be suggested after making a systematic analysis and theme identification. For the internal validity of the study, the integrity of the themes and contents of documents under analysis was achieved. Experts on this field were consulted about the concepts, themes and contents chosen for the study to ensure its credibility. Naive art, local subjects in art and self-educated artists were specified as the themes of the study. The interview form consists of 43 questions. The content of this form consists of questions on the lives of the artist, how they paint, which subjects they paint, how and where they exhibit their paintings, who buys them, which part of society is interested in their paintings, and how their paintings are received. The semi-structured interview form consists of open-ended and close-ended questions. In this context, written sources containing information about the problem were analyzed and deductions were made. The acquired data were supported with visual materials that were obtained by the same method and thought to be suitable for sampling.

The total number of photo-interpreter/realist and amateur painters comprises 48 persons. The sampling of this study includes 13 painters. As for the sampling method, criterion sampling was chosen from among other purposive sampling methods. This sampling method requires choosing persons, events, objects, or situations that have qualifications related to the problem of the study. ${ }^{33}$ Therefore, it is thought that the data ensures representation in terms of reliability. If the sample of the investigation is taken into detailed consideration, it is seen that this sampling consists of 13 painters, who are from the old and new generation of photo-interpreter/realists, working from Naive and amateur perspectives and persons from various parts of society (managers, writers, shopkeepers, archivists). The study was carried out with 3 painters and 5 persons from other classes among 13 painters.

A semi-structured personal questionnaire, which consists of questions concordant with the purpose of the study and which was developed by the researcher, was used as the data collection tool. The questionnaire consists of questions designed to receive information on the artistic lives of the painters, the development of local art, particularly that of painting, in Urfa, the knowledge of the painters on the art of painting, as well as information on how they work on the paintings and how they position their works.

Apart from the Naive painters, the presence of photo-interpreter/realist and amateur painters in Urfa could also be mentioned. Since they received education in painting courses and since they use documentary photographs and images of engravings on Urfa as sources in their works, photo-interpreter/realist and amateur painters are not included in this study.

(Konya: Eğitim Yayınevi. 2015), 381.

33 Şener Büyüköztürk, Ebru Kılıç Çakmak, Özcan Erkan Akgün, Şirin Karadeniz and Funda Demirel, Bilimsel Araştırma Yöntemleri (Ankara: Pegem Akademi Yayıncılık, 2010). 


\section{Findings and Commentary}

This section presents the findings obtained in accordance with the basic purpose of the research and commentaries related to them. Findings related to the topics chosen by the painters and the techniques and styles they applied to their works are interpreted in this part of the research. Painters who paint in naive perspective among the local painting tradition in Urfa were chosen at the beginning of the research process and then the naive paintings of these artists were compiled and evaluated.

\section{Naive Painters from Urfa and their Understanding of Painting}

With regard to the manner in which subjects are edited in the local painting tradition in Urfa and the connection they make with the viewers, it can clearly be seen that there is an important creativity and genius in the works of Naive painters who show a common tendency different from the painters working in a "photo-interpreter and realist style in Urfa." The Naive painters from Urfa carry out their art on the basis of their own world of imagination and impressions without having any intervention or help from their environment. They work individually throughout the process of creating this art. These paintings can be analyzed from a technical aspect and from the perspective of universal dimension. However, the main impression coming from these paintings is that the subject matters are the products of local minds and appreciation. It is possible to see the reflections of an intense realism as well as the influence of imaginary and oral folk literature, as well as traces of folkloric values in these pieces of art. It can be observed that these paintings of purity and simplicity were possibly created as a projection of life experiences in the imagination.

In this aspect, it can be stated that the works of the Naive painters from Urfa are far removed from the atmosphere of the environment of the art market, which consumes and assimilates, and they are important examples of authentic Naive art in Turkey that are produced without referring to contemporary, academic, or intellectual artistic norms. Painters, who interpret local life and folkloric themes as an important element and image with their style and point of view, and painters from various generations and movements are referred to in this study. The works of Namuslu Ali, Osman Güngör, Şefika Güneş, Naci Büyükkırcalı, Abdurrahman Birden, Abdurrahman Polat, Neşet Uçkan, Necmi Kaya and Muharrem Çelik, who are Naive painters from Urfa and who have produced pieces of art in accordance with the Naive art perspective and personal approaches independent from academic painting perspective and external influences have been examined on the Naive painting axis.

The most interesting painter among the Naive painters from Urfa is Ali Tökgöz, also known as Namuslu Ali [he is an auto painter by profession and originally from Diyarbakır (I. 5), (d.1970 (?) (I. 6)] because of his works and his colorful life. A Rus- 
sian painter (?), who was brought to Urfa by the mayor Ömer Alay in the 1930s to do the interior wall decorations of the Uray Hotel ${ }^{34}$ (currently Şair Nabi Kültür Merkezi), began producing paintings on the interior walls of the building. The works of this Russian painter attracted the attention of Namuslu Ali. According to the information at hand, Namuslu Ali occasionally went to watch the Russian painter and helped him and he was influenced by his works (I. 2). Namuslu Ali, who used empty shops and houses as his atelier (he used these spaces both as an atelier and home for himself) and lived a bohemian life in the neighborhoods in 1950s and 1960s was a renowned and popular sign-painter in Urfa at the time. It is known that, in the aforementioned periods when a new workplace was opened, people went straight to Namuslu Ali, since he was the most well-known sign-painter in Urfa. In that period, the doors of the pilgrims' houses, the walls of coffee houses, signs of shops, trailers and horse drawn carriages were ornamented. The paintings in the shops (for example, a lamb/meat painting portrayed on the side of the sign of a butcher's shop) by Namuslu Ali were mostly painted differently from the reality and in an interesting manner. He also painted the portraits of a great number of artisans in return for small gifts (a cup of tea or a wrap) and these portraits were made from an interesting Naive perspective (for example, he drew the ear of the person as big as the head and in a very simple way) (I. 1, 3).

Unfortunately, only two pictures by Namuslu Ali coloured with industrial oil and on wooden plaque, and the painting on Müslüm Parmaksız's house-wall have survived to today, even though he painted a great number of work-place signs and walls over an extended period of time (I. 8). These works portraying the Lake with Fish and the Urfa Castle (F. 3, F. 4, F. 5, F. 6) were painted in a Naive perspective and most likely by imagination. There is a little airplane in the sky in the painting The Lake with Fish (F. 3). It is thought that Namuslu Ali had probably encountered such a landscape and

34 It is stated that the paintings which portray Urfa on the walls of the stairs and rooms of the Uray Hotel, whose construction began in 1917 and was put into service in the first years of the republic and was later used as the municipal building and then demolished by the current mayor, were painted by a Russian painter about whom there is no information. (Some sources say that this painter is of Armenian origin [I. 5]) Unfortunately, paintings with seascape, hand-drawn decorations and paintings that portray Halil'ür-Rahman Lake and the Castle of Urfa next to the chamber painted by the same artist on the ceiling of a room next to this hotel have been erased by painting on them during the restorations performed lately (Some of the aforementioned paintings and ornaments have been documented by taking photos by Cihat Kürkçüoğlu in 1978). A landscape painting painted by the same painter on one of the walls of one of the rooms on the second floor of Şemsi Parmaksız House near Mevlevihane has reached the present day. Rumor has it that this Russian painter on whom no historical account exists was a spy and later was busted and tragically executed in Diyarbakir. Alongside with these rumours, Bekir Bozanoğlu made an interview with this allegedly Russian painter in Istanbul in 1957 and the painter told that he was invited by the mayor of the time, Ömer Alay (mayor of Urfa between 1933-1946) to paint and a man called Namuslu Ali took him as an apprentice when painting these paintings. He told that he went to see a circus that visited Urfa at that time and fell in love with a girl who worked there and then they eloped to Hilvan and settled down in an inn there. That very same night the district governor and public prosecutor asked him to release the girl he eloped with and he told him he would not. Upon this reply, he was arrested in Hilvan and put into prison. Later he was accused of being a Russian spy and brought to Diyarbakır and put into prison there and he was absolved after a certain time (I. 6). This aforementioned painter was known as aporter among the local people (I. 4). 
portrayed it using his memory. However, the trees were painted from imagination. The perspective in this piece of work is applied in different manners on the right and left of the picture. Even if the perspective of the buildings on the right is applied correctly the path on the left side of the painting is depicted as if it were descending. Since the Lake with the Fish is a place where Ali frequented every day (I. 1), architectural structures are portrayed more closely to reality. Dye is applied simply and only very thinly onto the surface. The picture called the Castle of Urfa (F. 4) was also painted in the same perspective and style. Certain places that depict the castle are portrayed with wide paint stains without drawing any details and only using a few colors. The structure of the castle and the houses at the forefront are shaped without detail with a slight, plain light-shadow. The two stone columns (catapult) are shown to be bigger than their actual sizes in exaggeration. It is seen that Namuslu Ali paid attention to the landscape design more than the castle itself. Trees and flowers in various heights are included.
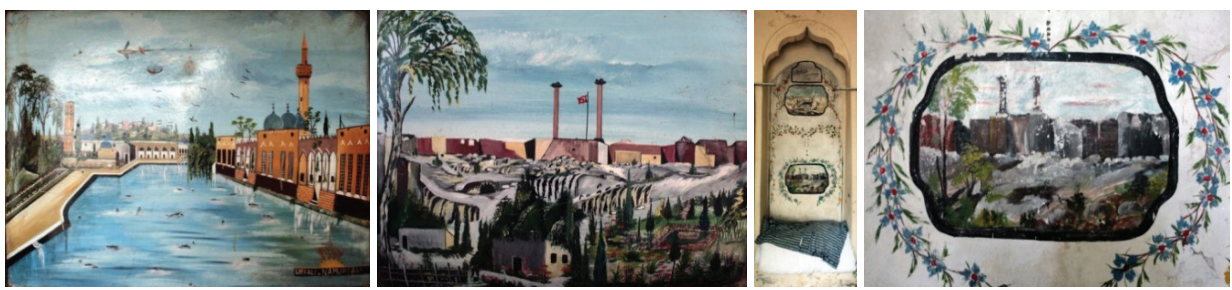

F. 3. Namuslu Ali, The Lake with Fish, 1967, Industrial Oil on Wooden Plaque, 65 x $84 \mathrm{~cm}$. (Sait Çoban and Atiye Zeynep Çoban Archive, Şanlıurfa, Photo by Burhan Akar, 2016).

F. 4. Namuslu Ali, Castle of Urfa, 1967, Industrial Oil on Wooden Plaque, 65 x $84 \mathrm{~cm}$. (Sait Çoban and Atiye Zeynep Çoban Archive, Şanlıurfa, Photo by Burhan Akar, 2016).

F. 5. Namuslu Ali, 1961, The painting on the house wall of Müslüm Parmaksiz Industrial oil, Kadıoğlu Mahallesi, İrfaniye Sokak, Şanlıurfa, Photo by Burhan Akar, 2016).

F. 6. Namuslu Ali, Castle of Urfa (Detail from the Wall), 1961, Industrial Oil on Wall, Kadioğlu Mahallesi, İrfaniye Sokak, Şanlıurfa, Photo by Burhan Akar, 2016).

One of the important Naive painters from Urfa evaluated in this article is Osman Görgün. Görgün, who was born in 1929 and began painting when he was a child. He painted a great number of paintings and calligraphic pieces of art in the workshop assigned to him in Şanlıurfa State Gallery of Fine Arts with the support and encouragement of the manager Nevin Güllüoğlu. The subjects of Görgün's works are mostly roosters and cockfights. His pieces of art give the feeling that they were painted with an academic consciousness in some respects (technique and composition) (F. 7, F. 8). However, when his paintings are examined more closely, it can clearly be seen that Naive conception dominates the imagination and the design of the paintings and that there is no compulsory painting. The painting seems to have been produced in an easy and sincere manner. 

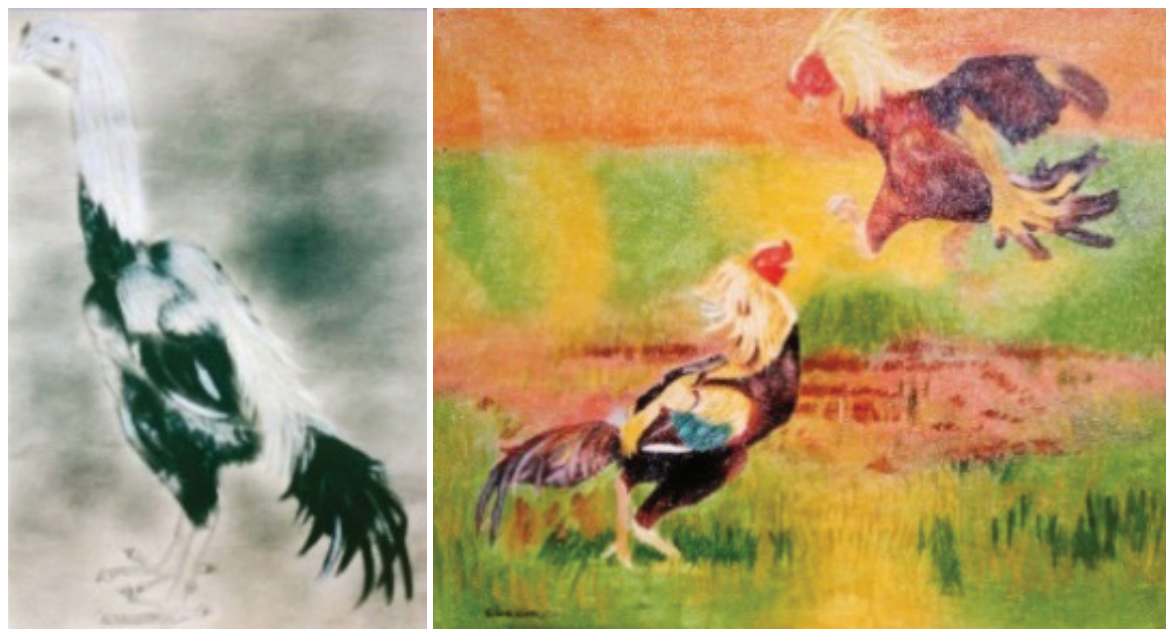

F. 7. Osman Güngör, Rooster, 1987, Oil on Canvas, 20 x 29 cm. (Şanlıurfa State Fine Arts Gallery Archive, Şanlıurfa. Şanlıurfa Valiliği, Şanlıurfalı Ressamlar, 13).

F. 8. Osman Güngör, Cockfight, 1989, Oil on Canvas, 50 x $55 \mathrm{~cm}$. (Şanlıurfa State Fine Arts Gallery Archive, Şanlıurfa. Şanlıurfa Valiliği, Şanlıurfalı Ressamlar, 14).
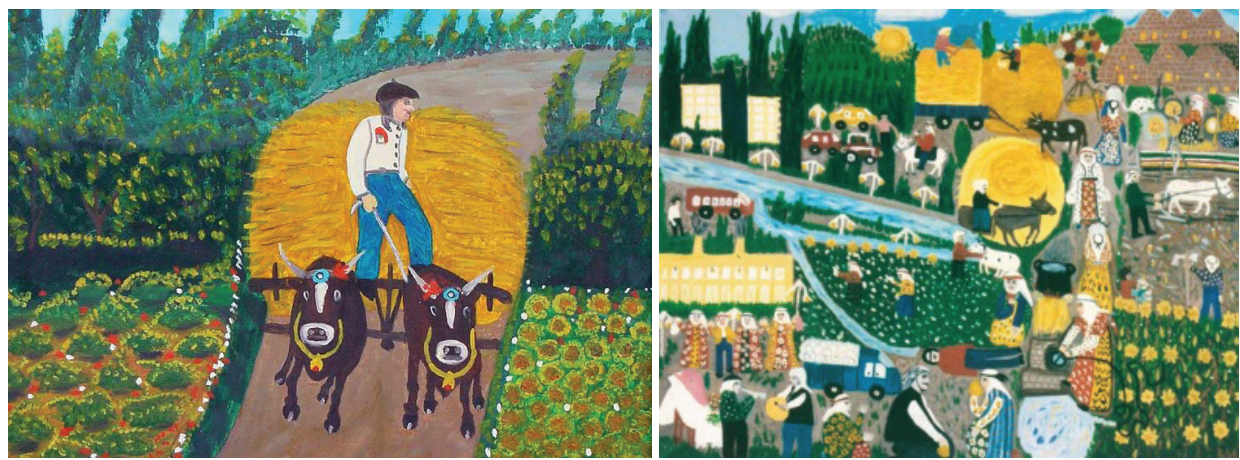

F. 9. Şefika Güneş, Oil on Canvas (Ahin Güneş Archive, Şanlıurfa. http://wwww.supersatforum. com/resim-ve-fotograf-dunyasi/17588-ressam nine.html.).

F. 10. Şefika Güneş, Water Came, the Era has Changed in Harran, 1994, Oil on Canvas, 81 x 103 cm. (Şanlıurfa Valiliği, Şanlıurfalı Ressamlar,16).

Şefika Güneş (1937-2015) is another outstanding painter in the group. It is possible to see traces of life in the village where she was born and raised, as well as the influence of the local folk literature from which she benefitted to a large extent. In the works of Güneş, who was illiterate and began painting later in life, threshing fields, harvest season and portrayals of women ploughing and herding the flocks with local motifs are depicted in an almost epic sincerity. Güneş was able to protect a great many elements related to her childhood memories and landscapes without aspiring to the artistic understanding of academic and photo-interpreter/realist/amateur painters in her 
environment and without losing her Naive character. She was thus able to reflect these into her painting with a simple reality. ${ }^{35}$ It immediately strikes the eye that Güneş's paintings, unlike those of other Naive artists, did not come into existence with the intent of making a simple reproduction of what was traditional and ordinary within Naive art (Her paintings seem to have taken their shape in accordance with their essence and stories). Each of her paintings emerged as pictures that tell and interpret their own story without any formal manipulations and without repetition of subjects. Elements such as exaggeration, simplicity, plainness and grandeur in her paintings are not there to escape from reality. The presence of such elements does not indicate her inability to capture reality, it is rather because of the priority that she placed on imagination and enthusiasm. It can be seen that in Güneş's paintings, decorations like traditional folk art occupy a significant place; raw colors are used, a simple painting stands out rather than a fine craftsmanship and decorations are reflected without being unnatural. What Ani Toros said for Paul Klee's art can also be said for Güneş's art: "Klee's art shared a kind of animism that resembles the works of children and primitive art very much, everything has a spirit in a pantheistic background." ${ }^{36}$ Güneş's paintings, which create an impression that they benefited from the folk tradition and literature on a large scale (F. 9, F. 10), can be evaluated as Naive expressionist paintings that are painted with an improvised coloring, with the guidance of instincts and from the depths of consciousness.

Naci Büyükkırcalı (1952-), who is a retired worker, portrays the now lost handicrafts of Urfa, ruined, demolished and damaged buildings, scenes from the daily lives of inhabitants of old Urfa. He paints these with a patient and meticulous painting technique using a unique Naive style language. It can be said that the paintings of Büyükkırcalı stand in between Naive and non-Naive, because he uses his brush skillfully and some of his paintings have strong compositions and are painted with a technique stylized and colored with great attention and caution as well. The space and figures are portrayed delicately with fine brush strokes (F. 11, F. 12, F. 13, F. 14).

35 After Şefika Güneş’s became a renowned artist in Urfa, some painters she knew advised her to take lessons to improve her perspective and to improve artistic aspects of her art in an academic manner. She also became involved in such a search herself later on. Anyhow, after some other academician masters told her that she could paint without any academic artistic knowledge like many other Naive painters around the world, Güneş continued to paint with her childish sensitivity and character without any intervention. Some experts, who noticed that Güneş painted with Naive sensitivity, paid attention to her and enabled her to display her works on a good number of exhibitions. (see also Mustafa Güneş, "Ressam Nine Şefika", accessed 09 December 2018. http://www. haberninova. com/makale/yazar---mustafa-gunes/ressam-nine-sefika/60.html).

36 Ani Toros, "Paul Klee", Adam Sanat Dergisi 65 (1991), 69. 

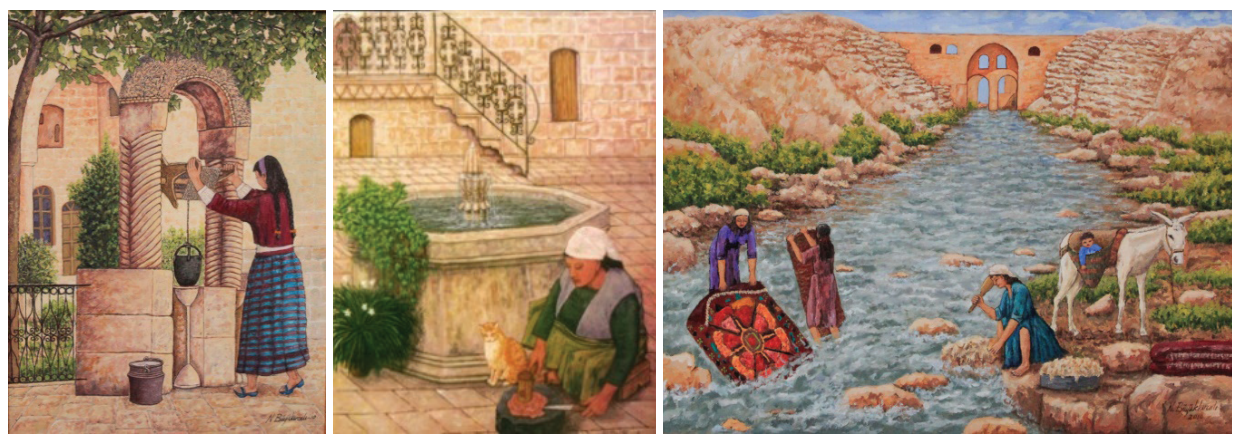

F. 11. Naci Büyükkırcal1, Woman Extracting Water from the Well, 2010, Oil on Canvas, $80 \times 100$ cm. (Şanlıurfa Provincial Directorate of Culture and Tourism Archive, Şanlıurfa. http://www. urfakultur.gov.tr /TR 65525/ ressamlarin fircasindan.).

F. 12. Naci Büyükkırcal1, Woman Tendering the Meat at Karataş, 2007, Oil on Canvas, 80 x 100 cm. (Naci Büyükkırcalı Archive, Şanlıurfa, Photo by Sait Toprak, 2018).

F. 13. Naci Büyükkırcalı, Washers of Carpets and Wool in Karakoyun, Oil on Canvas, $60 \times 80$ cm. (Şanlıurfa Provincial Directorate of Culture and Tourism Archive, Şanlıurfa. http://www. urfakultur.gov.tr /TR 65525/ ressamlarin fircasindan.).

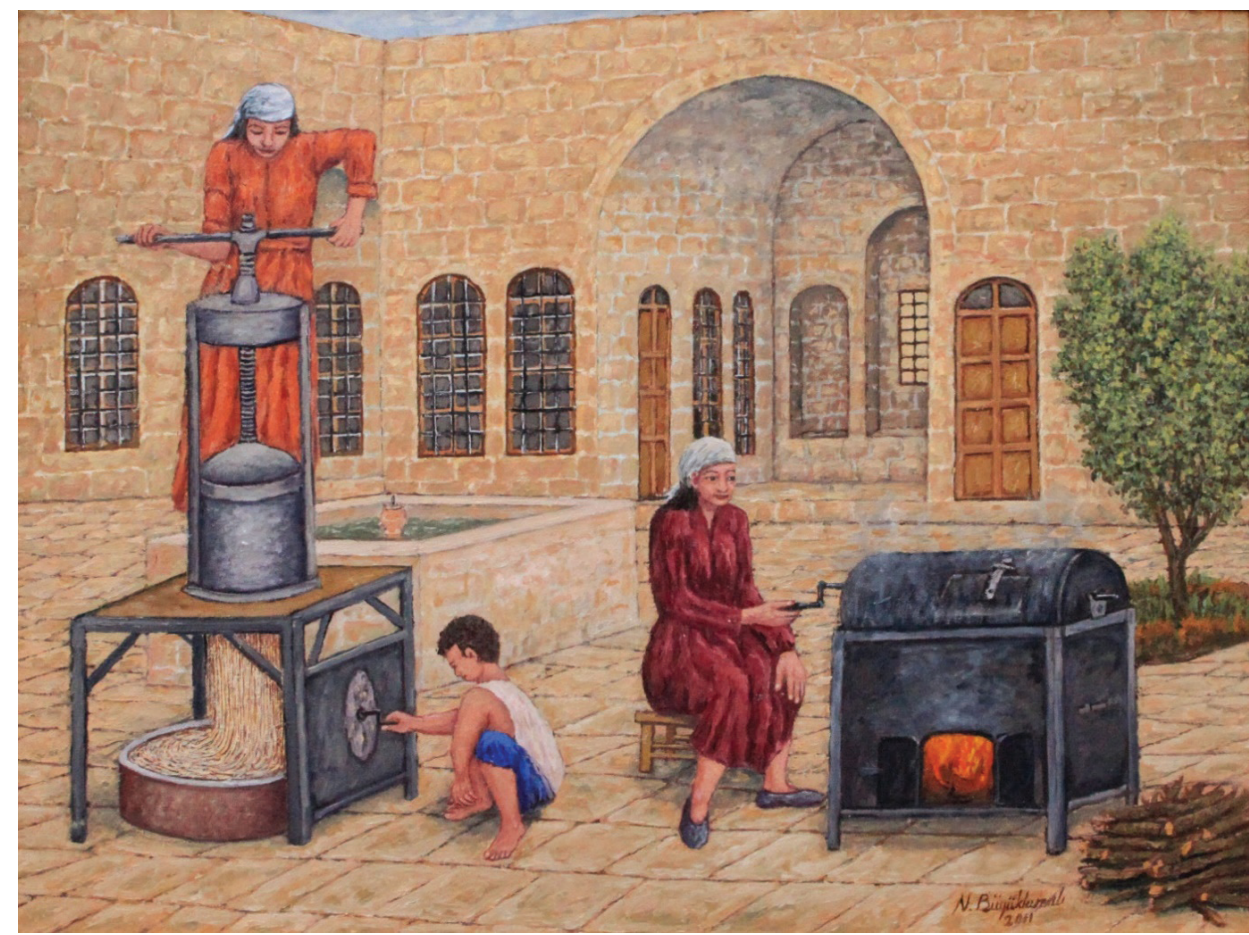

F. 14. Naci Büyükkırcalı, Time of Vermicelli, Oil on Canvas, 60 x $80 \mathrm{~cm}$. (Şanlıurfa Provincial Directorate of Culture and Tourism Archive, Şanlıurfa. http://www.urfakultur.gov.tr /TR 65525/ ressamlarin fircasindan.). 
Despite the fact that his painting is performed in a skillful manner, the portrayal and presentation of figures have come out as a product of a childish perception and sensitivity. These two sides of Büyükkırcalı enabled him to obtain a different language. The following statement of Fahir Aksoy referring to Louis Vivin, who is also a Naive painter, is valid for the paintings of Büyükkırcalı as well: "(...) like a mason, he painted the architecture by putting one stone on top of another." ${ }^{37}$ The figures portrayed in the pictures of Büyükkırcalı are the residual images of life experiences that have remained in his memory. His paintings never look alike to one another, and they are far from being anonymous. Even if the figures are composed with a similar style of painting, they are always portrayed with an understanding that shows their unique character.

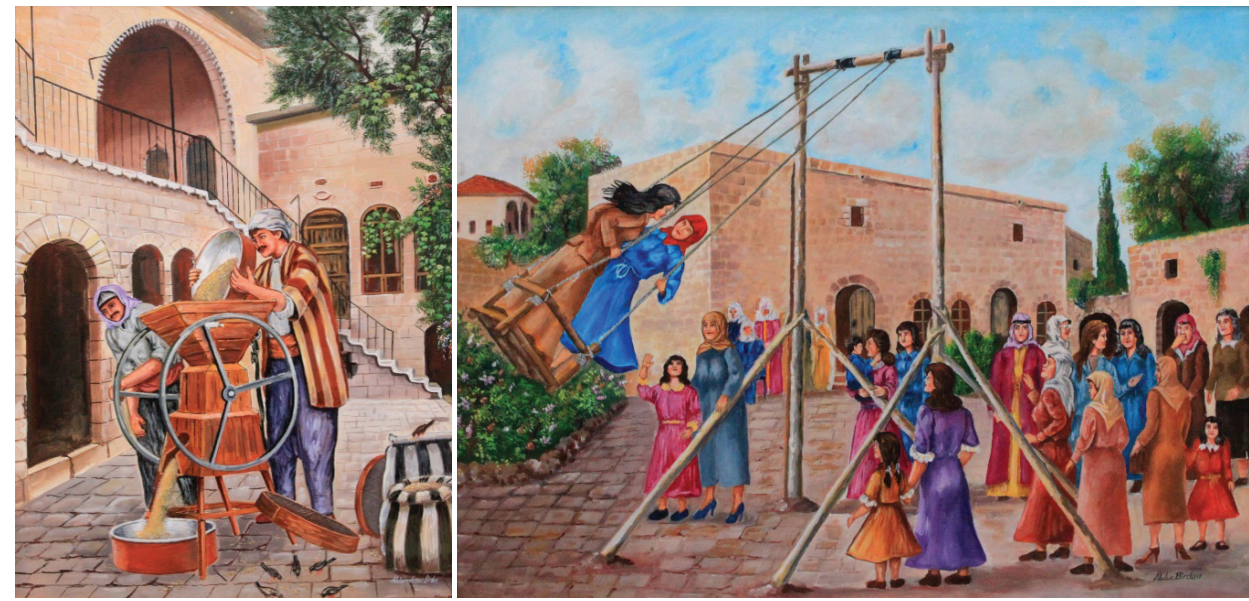

F. 15. Abdurrahman Birden, Oil on Canvas. (Şanlıurfa Provincial Directorate of Culture and Tourism Archive, Şanlıurfa. http://www.urfakultur.gov.tr /TR 65525/ ressamlarin fircasindan.).

F. 16. Abdurrahman Birden, Oil on Canvas. (Şanliurfa Provincial Directorate of Culture and Tourism Archive, Şanlıurfa. http://www.urfakultur.gov.tr /TR 65525/ ressamlarin fircasindan.).

Scenes from everyday life in Urfa catch attention through the greater part of the paintings of Abdurrahman Birden (1945-), who began painting after working as an easel sign painter (I. 4). Wooden swings and carousels that were set up in various neighborhoods of Urfa in every religious festival, the vermicelli machines that were set up in street alleys, and carpet weavers seem to have left a mark on Birden's memory. Birden produces art portraying such scenes with his pure and genuine style. It is evident that Birden (F. 15, F. 16), using a Naive style, also produces his paintings patiently with fine brush strokes and transitions and also with the rigor of a sign painter. 

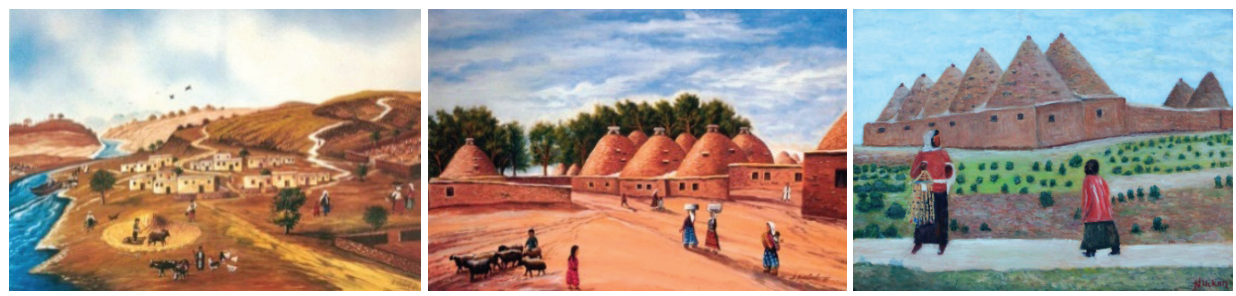

F. 17. Abdurrahman Polat, On the Banks of the Euphrates, 1991, Oil on Canvas, 48 x $68 \mathrm{~cm}$. (Şanlıurfa State Fine Arts Gallery Archive, Şanlıurfa. Şanlıurfa Valiliği, Şanlıurfalı Ressamlar, 33). F. 18. Abdurrahman Polat, Harran, 1991, Oil on Canvas, 48 x 68 cm. (Şanlıurfa State Fine Arts Gallery Archive, Şanlıurfa. [Şanlıurfa Valiliği, Şanlıurfalı Ressamlar, 34).

F. 19. Neşet Uçkan, Harran, Oil on Canvas. (Şanlıurfa Provincial Directorate of Culture and Tourism Archive, Şanlıurfa. http://www.urfakultur.gov.tr /TR 65525/ ressamlarin fircasindan.).

Abdurrahman Polat (1945-2017) is another Naive painter, who is also an easel sign painter by profession. Over many years, Polat decorated trucks, trailers, schools, official buildings, coffeehouses, walls of pilgrims' houses and religious places with his works (I. 3); and when he had time to spare, he made an important contribution to the diversification and development of the Naive painting in Urfa in terms of subject and style with his paintings created with childlike enthusiasm and craftsmanship, portraying rural life with his unique emphasis. Any kind of intervention or guidance cannot be observed in these works which he created purely out of his own imagination (F. 17, F. 18). On the contrary, they were painted with a Naive and meticulous sensitivity. When Polat's paintings are observed closely, it is understood that they were painted from the point of view of a mature child.

It immediately strikes the eye that in most of the paintings, the enthusiasm and excitement of the painter is in the foreground. This is particularly evident in the painting entitled On the Banks of the Euphrates (1991) (F. 17) which is a work of art that gives much joy. The painting depicts the cycle of life in the village. Every element in the painting seems to have been painted with a sincere and Naive sensitivity. In this context, it can be determined that he had the desire to reflect life as he witnessed it rather than the desire to mature in terms of technique and pictorial value, and this is dominant in the passion of Polat's portrayal in his paintings. Accordingly, since this aspect is prominent in the paintings it can be said that he is also a visual storyteller as well as being Naive. 


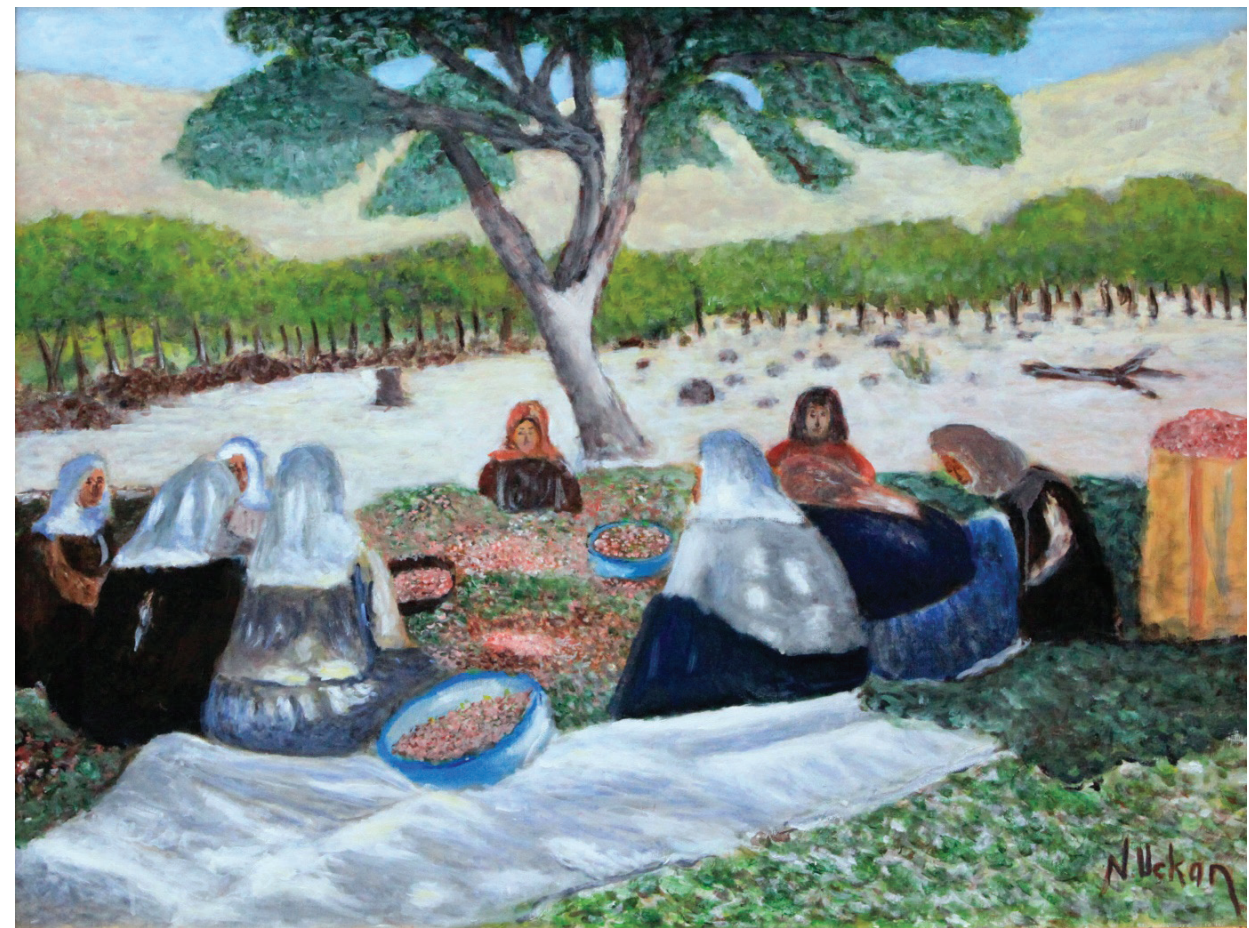

F. 20. Neşet Uçkan, Harvest of Pistachios, Oil on Canvas. (Şanlıurfa Provincial Directorate of Culture and Tourism Archive, Şanlıurfa. http://www.urfakultur.gov.tr/TR 65525/ ressamlarin fircasindan.).

It is noteworthy that Neşet Uçkan (1947-), who is a pharmacist by profession and who started painting later in life, does not have a beautifying, forceful style (an anxiety for painting is not observed) in his quiet and relaxing paintings (F. 19, F. 20). ${ }^{38}$ The painting called The Pistachio Harvest is one of his important works and is produced in a Naive perspective (F. 20). The painting was created with small brush strokes suitable for the subject in a simple style without detail. The functions of figure and space stand more within the Naive understanding of pictorial art and far away from the academic understanding. 


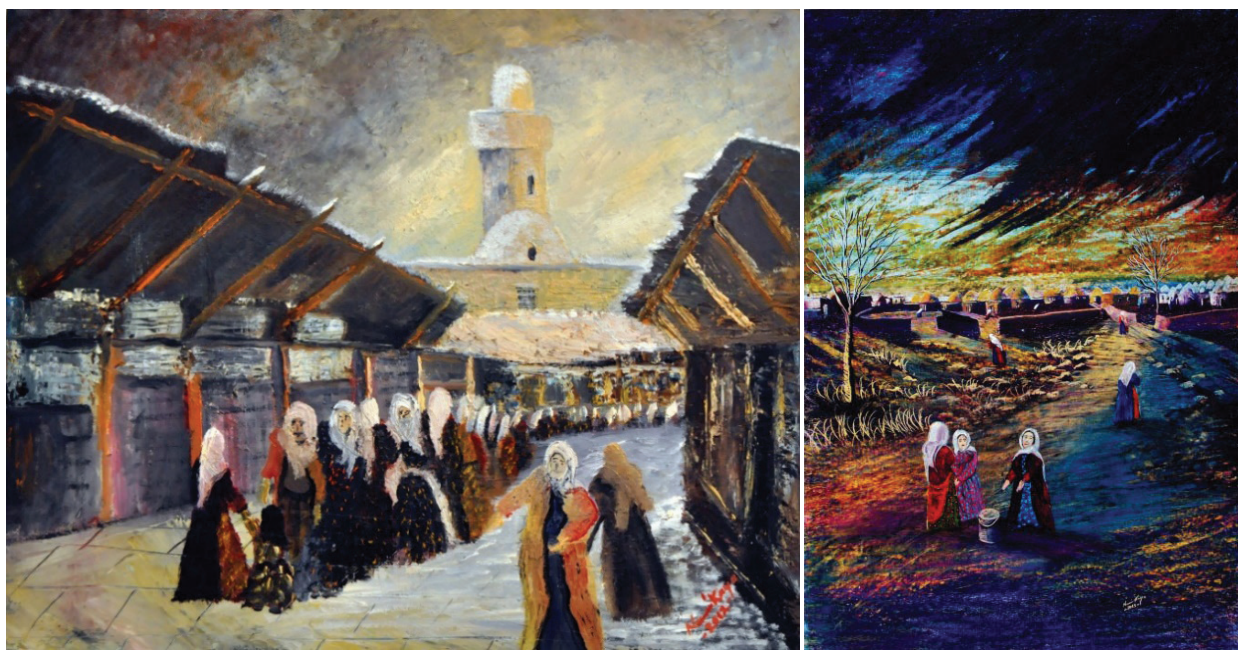

F. 21. Necmi Kaya, Urfa, 2012, Oil on Canvas. (Necmi Kaya Archive, Şanlıurfa, Photo by Sait Toprak, 2016).

F. 22. Necmi Kaya, Harran, 2012, Pastel on Canvas, 70 x 100 cm. (Necmi Kaya Archive, Şanliurfa, Photo by Sait Toprak, 2016).

Necmi Kaya (1958-) stands out among the Naive painters from Urfa in terms of his subjects and technique with his paintings of Harran, which he has been consistently painting with pastel (I. 7) since 1985. He has developed a genuine Naive language in painting. A variety of scenes from traditional life in Harran are seen in the paintings of Kaya. In these scenes it can be observed that he has produced a series of consistent visual thoughts relating to the Harran landscape with a pure sincerity. His paintings, (F. 21, F. 22) which he painted with pastels forming a layered surface on the oil texture, show that pastel can be used by a Naive painter as a unique technique. The figures Kaya portrayed based on images are always presented in local outfits. These figures are in an organic integrity with the space in which they are portrayed, in terms of style and meaning. Kaya has created an important Naive aesthetic value by consistently, successfully and sincerely depicting scenes of real life from Harran without losing his sensitivity and without aspiring to other painting perceptions in his paintings.

Muharrem Çelik (1974-), who has not received an academic education in painting, has a distinctive place among the Naive painters from Urfa with his expression and style of the extraordinary contents in his art. In his paintings, which we can evaluate as Naive expressionist in terms of the portrayal of the images, he extensively uses raw and pastel colors. In his works, where a Naive sensitivity as well as humor and satire exist, quaintness and sincerity are felt in various aspects. Some of the paintings of this painter, who is sensitive to social solidarity and who participated voluntarily in a lot of activities in this respect, have contents that closely examine social subjects. 
In the paintings, where there are no details and a shallow paint is applied, all of the elements are produced as an extension of the artist's imagination and it is seen that the painter does not have the intention to create a beautiful image (F. 23, F. 24, F. 25). An unfinished atmosphere is felt in his paintings, in which some noncoercive, simple and symbolic characteristics can be seen. Though Çelik's paintings are at first sight perceived to be easily made, in fact, they have to be evaluated as paintings in which the painter observes his environment in a realistic manner and expresses the thoughts derived from these observations. "Generally, it is stated that the Naive artists do not aim at giving a message through their art. However, even if there is no rule dictating the Naive artists to convey a message, it is occasionally seen that some of them present the dramatic life of a region with their art." ${ }^{39}$ In fact, portraits of women in a series of paintings by Çelik entitled Zelo, which he painted in similar composition, seem to point at the problems of women living in the region where he lives. The painting called Bleeding Zelo Wearing the White Hand-Painted Kerchief (F. 23) ${ }^{40}$ contains an important expression that originates from instinctive nature in spite of the fact that it is portrayed in a shallow and simple manner in terms of plastic language. Like many other Naive painters, Çelik, too, makes use of folk art in creating the setup of his paintings.
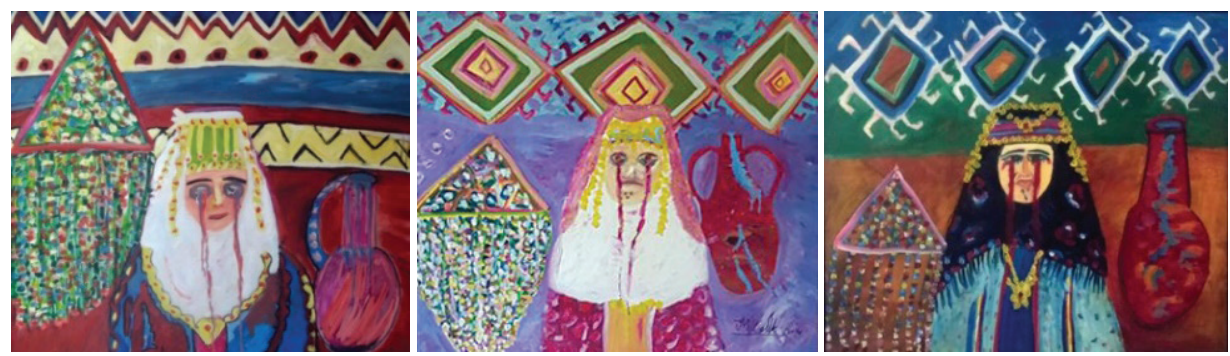

F. 23. Muharrem Çelik, Bleeding Zelo Wearing the White Hand-Painted Kerchief, 2014, Oil on Canvas. (Muharrem Çelik Archive, Şanlıurfa. http://asanliurfa.blogspot.com/2013/05/zelo-nedenaglyor-tablosu.html.).

F. 24. Muharrem Çelik, 2014, Oil on Canvas. (Muharrem Çelik Archive, Şanlıurfa).

F. 25. Muharrem Çelik, 2014, Oil on Canvas. (Muharrem Çelik Archive, Şanlıurfa).

\section{Conclusion}

Naive painters from Urfa, who can be regarded as having an aesthetic value that has been undervalued in Turkish Naive painting, have portrayed life in their environments with a perception, which is personal, aesthetic, fictional, pure and meticulous. It has been observed that Naive painters from Urfa created a special way of expression in painting and followed a consistent development line by dwelling on images from

39 Aksoy, Naif Sanat ve Türk Naifleri, 9.

40 Accessed 07 December 2018, http://www.urfadabugun.com/haber/111067/.html. 
life in the region. They have the accumulation and originality with which they can introduce a certain vividness and a new point of view to Naive art in Turkey with their subjects, techniques and styles.

Painters who work with a Naive style in the local painting tradition of Urfa have succeeded in forming a personal, strong and Naive expression in painting around a common subject peculiar to them, within the framework of general characteristics of Naive painting by integrating local mind and taste, without being incorporated into any artistic style and getting any intervention and help from their environment in the process of production and by staying out of the art market.

When one observes the paintings of the Naive artists from Urfa, it can be seen that each of the painters produce works in accordance with their own instincts and intuitions by drawing on their own experiences in life and reality. In some of the examples analyzed here, it is clear that there is a realist and pedant painting style and that there are transitions to soft colors, while in some other examples a more superficial and plain design prevails. Depending on personal artistic experience and accumulation, some of the painters have been observed to have created their paintings by using a strong composition, figure and perspective. As regards some other examples, a pure depiction with a childish sensitivity have been observed. The paintings in which scenes from local life are intensively portrayed can also be qualified as visual documents at the same time.

The paintings of Naive painters from Urfa have been valued equally with handicrafts and other arts in Urfa. Their spheres of influence have been widened and they have attracted the attention of the public and taken an important place in the cultural life of the city (I. 7). Naive painters from Urfa, who play an effective role in their own narrow media, should receive the appreciation that they deserve in the national and international world of art by being evaluated in their own category.

Peer-review: Externally peer-reviewed.

Conflict of Interest: The author has no conflict of interest to declare.

Grant Support: The author declared that this study has received no financial support.

Acknowlegements: I thank Göknur Karaduman for the translation of the article from Turkish to English.

Hakem Değerlendirmesi: Dış bağımsız.

Çıkar Çatışması: Yazar çıkar çatışması bildirmemiştir.

Finansal Destek: Yazar bu çalışma için finansal destek almadığını beyan etmiştir.

Teşekkür: Makalenin Türkçe'den İngilizce'ye çevirisi için Göknur Karaduman'a teşekkür ediyorum. 


\section{References/Kaynakça}

Aksoy, Fahir. Naif Sanat ve Türk Naifleri. İstanbul: Ak Yayınları, 1990.

Becker, Howard Saul. Sanat Dünyaları. Translated by Evren Yılmaz. İstanbul: Ayrıntı, 2003.

Berg, Bruce L. and Howard Lune. Sosyal Bilimlerde Nitel Araştırma Yöntemleri. Edited by Hasan Aydın. Konya: Eğitim Yayınevi/Pearson, 2015.

Büyüköztürk, Şener, Ebru Kılıç Çakmak, Özcan Erkan Akgün, Şirin Karadeniz and Funda Demirel. Bilimsel Araştırma Yöntemleri. Ankara: Pegem Akademi Yayıncılık, 2010.

Erdem, Sevim. Modern Sanat. İstanbul: Türkiye Basımevi, 1963.

Erzen, Jale. Eczacıbaşı Sanat Ansiklopedisi. Vol. 2. İstanbul: Yem Yayın, 2008.

Gombrich, Ernst H. Sanatın Öyküsü. Translated by Erol Duman and Ömer Erduman. İstanbul: Remzi Kitabevi, 1999.

Güneş, Mustafa. "Ressam Nine Şefika". Accessed 09 December 2018. http://www. haberninova. com/makale/yazar---mustafagunes/ressam-nine-sefika/60.html.

Library of Universal Knowledge-The Practical Self-Educator. Edited by Franklin J. Meine. Chicago: Consolidated Book Publishers, 1963.

Manukyan, Ayda Şirin. Naif Resmi, Cumhuriyetin Renkleri ve Biçimleri. Edited by Ayla Ödekan. İstanbul: Tarih Vakfı Yayınları, 1999.

Özsezgin, Kaya. Sanat Üzerine Yazılar. İstanbul: Cumalı Sanat Galerisi Yayınları, 1982.

Read, Herbert. Sanatın Anlamı. Translated by Güner İnal and Nuşin Asgari. İstanbul: Türkiye İş Bankası Kültür Yayınları, 1974.

Saraç, Simge. “Türkiye'de Naive Resim”. M. A. Thesis, Istanbul University, 1988.

Sözen, Metin and Uğur Tanyeli, Sanat Kavram ve Terimleri Sözlüğü. İstanbul: Remzi Kitabevi, 2007.

T.C. Şanlıurfa Valiliği. Şanlıurfalı Ressamlar. İstanbul: Küre Basım Yayım San. ve Tic. Ltd. Şti., 2001.

Tansuğ, Sezer. Türk Resminde Yeni Dönem. İstanbul: Remzi Kitabevi, 1990.

Toros, Ani. "Paul Klee.” Adam Sanat Dergisi 65 (1991): 69.

Accessed 08 December 2018. http://all-art.org/art_20th_century/modern_art/Naive\%20art1.htm

Accessed 22 January 2019. https://arthive.com/henrirousseau/works/324683 Landscape_with_a_dirigible.

Accessed 07 December 2018. http://asanliurfa.blogspot.com/2013/05/zelo-neden-aglyor-tablosu. html.

Accessed 22 January 2019. http://www.canvasreplicas.com/Rousseau105.htm.

Accessed 21 November 2018. http://www.urfakultur.gov.tr/TR 65525/ressamlarin fircasindan.

Accessed 07 December 2018. http://www.urfahizmet.com/yazarlar/kose_yazilari/konuk_yazar/4587.

Accessed 07 December 2018, http://www.urfadabugun.com/haber/111067/.html.

"Hayırseverliğin sanatçılıkla birleşiği isim; Neşet Uçkan," Accessed 07 December 2018. http:// gapgundemi.com/haber-hayirseverligin_sanatcilikla_birlesigi_isim_neset_uckan-16561.html.

Accessed 07 December 2018. http://www.supersatforum.com/resim-ve-fotograf-dunyasi/17588ressam nine.html. 


\section{Interviews}

I: 1: Naci İpek, born on 1930, university graduate, writer in local newspapers.

I: 2: Bekir Bozanoğlu, born on 1938, lawyer, died in 2019 (Archive of Cihat Kürkçüoğlu), 2018.

I: 3: Abdurrahman Polat, born on 1945 in Urfa, founded an advertising and graphics workshop in 1964, graduated from Mersin Teacher's Training School in 1967, worked as a primary school teacherin elementary schools in Urfa. Polat who painted in Naive style died in 2017.

I: 4: Abdurrahman Birden, born on 1945 in Urfa, gradated from secondary school, he founded an advertising and graphics workshop in 1963 and he started painting around this time.

I: 5: Fuat Teber, born on 1948 in Urfa, retired civil servant.

I: 6: Fehmi Tokgöz, born on 1954 in Urfa, works as a car body repairer.

I: 7: Necmi Kaya, born on 1958 in Urfa, graduated from Urfa Institute of Education in 1979, worked as a primary class teacher in elementary schools in Şanlıurfa. Kaya paints on Urfa in Naive style.

I: 8: Burhan Akar, born on 1963 in Urfa, works as an accountable in Şanlıurfa City's Directorate of the Culture and Tourism. 
